

Check for updates

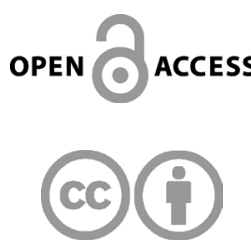

Corresponding author:

L. V. Duarte

lduarte@dct.uc.pt

\section{Journal webpage:}

http://cienciasdaterra.novaidfct.pt/index. php/ct-esj/article/view/353

\section{Copyright:}

(C) 2017 L. V. Duarte et al. This is an open access article distributed under the terms and conditions of the Creative Commons Attribution License (CC BY), which permits unrestricted use, distribution, and reproduction in any medium, provided the original author and source are credited.

\title{
The Lower Jurassic at Peniche (Lusitanian Basin): recent advances in Stratigraphy and Sedimentary Geology
}

\author{
L. V. Duarte', E. Mattioli², R. B. Rocha ${ }^{3} \&$ R. L. Silva ${ }^{4}$ \\ ${ }^{1}$ MARE, Universidade de Coimbra, Departamento de Ciências da Terra, Faculdade de Ciências e Tecnologia, \\ Largo Marquês de Pombal, 3000-272 Coimbra, Portugal. lduarte@dct.uc.pt. \\ ${ }^{2}$ Univ. Lyon, Université Claude Bernard Lyon 1, ENS de Lyon, CNRS, UMR 5276 LGL-TPE, F-69622 \\ Villeurbanne, France. emanuela.mattioli@univ-lyon1.fr \\ ${ }^{3}$ GeoBioTec, Earth Sciences Department, Faculty of Sciences and Technology, Universidade NOVA Lisboa, \\ Campus de Caparica. 2829-516 Caparica, Portugal.rbr@fct.unl.pt \\ ${ }^{4}$ Basin and Reservoir Lab, Department of Earth Sciences, Dalhousie University, Halifax, Canadá. ricardo. \\ silva@dal.ca
}

\section{Abstract}

In the Lusitanian Basin (west-central Portugal), the Lower Jurassic deposits are well exposed and are dominated by carbonates. Framed by a beautiful and unique Atlantic coastal landscape, the Peniche Peninsula shows the most important and continuous section of the Lower Jurassic in Portugal, providing a record of around $20 \mathrm{Myr}$ of Portuguese geological history (Sinemurian to Toarcian). The importance of this site is testified by the large number of recent research studies in different domains of sedimentary geology and stratigraphy. This field-trip focuses on three main topics of international scientific interest: a) the Sinemurian and Pliensbachian organic-rich deposits, one of the chief intervals of hydrocarbon source potential in the western Iberian margin; b) the Pliensbachian-Toarcian boundary at Ponta do Trovão, which has been ratified as the Toarcian Global Boundary Stratotype Section and Point (GSSP); and c) the early Toarcian oceanic anoxic event recorded at Abalo beach.

Keywords: Lower Jurassic, Stratigraphy, Palaeoenvironment, Peniche, Portugal.

\begin{abstract}
Resumo
Na Bacia Lusitânica (centro-oeste de Portugal) o Jurássico Inferior está muito bem representado e exposto, através de um claro domínio de sedimentos carbonatados. Enquadrada por uma paisagem costeira de elevada beleza cénica, a península de Peniche mostra a secção mais contínua e completa do Jurássico Inferior de Portugal, representando um registo de cerca de 20 milhões de anos da sua história geológica (Sinemuriano a Toarciano). A importância deste local é testemunhada pelo vasto número de atividades de investigação científica recentemente realizadas, relacionadas com diferentes domínios da geologia sedimentar e estratigrafia. Sendo assim, esta saída de campo é focalizada em três principais temas de interesse científico internacional: a) a sedimentação rica em matéria orgânica do Sinemuriano e Pliensbaquiano, um dos principais intervalos potencialmente geradores de hidrocarbonetos da margem ocidental da Península Ibérica; b) o limite Pliensbaquiano-Toarciano em Ponta do Trovão, ratificado como estratótipo (Global Boundary Stratotype Section and Point, GSSP) do limite Pliensbaquiano-Toarciano; c) o evento oceânico anóxico do Toarciano Inferior registado na praia do Abalo.
\end{abstract}

Palavras-chave: Jurássico Inferior, Estratigrafia, Paleoambiente, Peniche, Portugal.

${ }^{a}$ This proposition was unanimously ratified by the IUGS Executive Committee in December 2014. Consequently, the GSSP for the base of the Toarcian is accepted as the base of bed 15e (base of the Polymorphum Zone) at the Ponta do Trovão (Peniche) section.

ISSN: $0254-055 \mathrm{X}$ eISSN: 2183 - 4431

\section{Introduction}

One of the best expressed records of Early Jurassic is observed in the Lusitanian Basin (LB), located in the western sector of the Iberian Peninsula, corresponding in the main to a thick marine carbonate series (Fig.1; e.g., Soares et al., 1993; Azerêdo et al., 2003; Duarte et al., 2004). Part of this succession, namely the interval between the Sinemurian and the Toarcian stages, is dominated by marl-limestone alternations. 
Several outcrops of the LB provide crucial information about the Lower Jurassic. The reference section of Peniche (Fig. 2), located about $80 \mathrm{~km}$ north of Lisbon, presents the most complete succession of Lower Jurassic sediments in Portugal, framed by an important geological heritage character and a spectacular scenic environment (Duarte, 2004). In recent years, this section has been the focus of intense scientific activity, related mainly to stratigraphy and sedimentary geochemistry (e.g., Rocha, 2007; Hesselbo et al., 2007; Suan et al., 2008a, 2008b, 2010; Mattioli et al., 2008, 2009; Duarte et al., 2010, 2011; Reggiani et al., 2010a, 2010b; Silva et al., 2011b, 2012). In addition to introducing the sedimentary context, describing the stratigraphy, and characterizing the whole succession (Stop 1), on this field-trip we also discuss: a) the Pliensbachian organic-rich marl-limestone deposits, one of the main intervals of hydrocarbon source potential in the West Iberian Margin (Stop 2); b) the Pliensbachian-Toarcian boundary at Ponta do Trovão, which has been ratified as the Toarcian Global Boundary Stratotype Section and Point (GSSP) (Stop 3); and c) the early Toarcian oceanic anoxic event (T-OAE) and its record at Abalo beach (Stop 4). All of these themes are presented and supported by an integrated stratigraphic analysis involving a range of sedimentological, geochemical, and palaeontological methodologies.

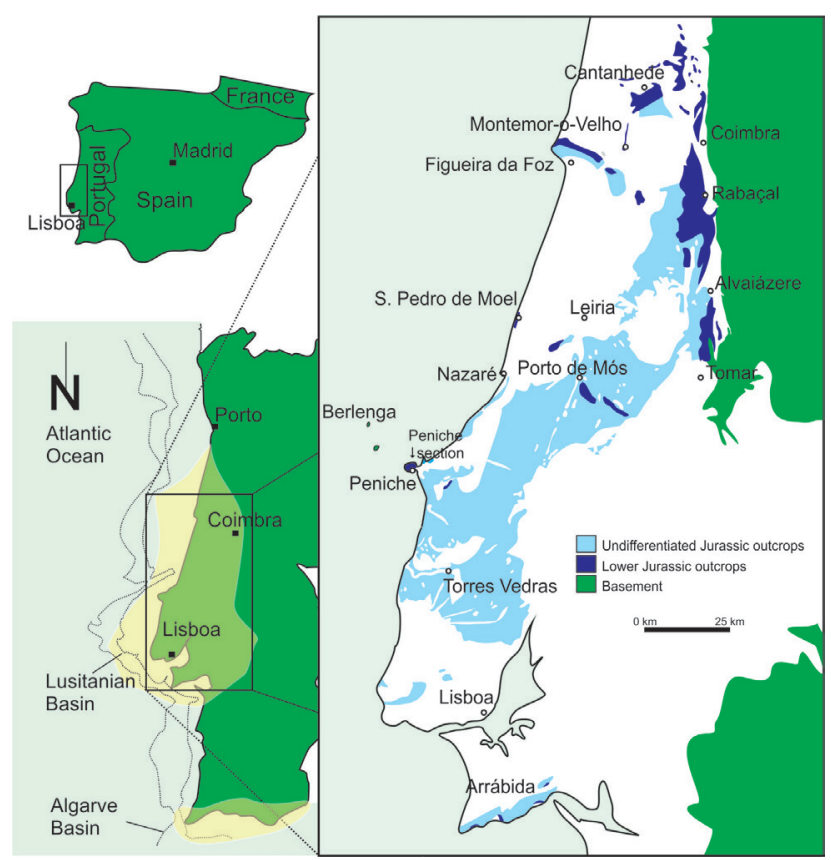

Fig. 1 - Simplified geological map of the central-northern part of the Lusitanian Basin (Portugal) showing the distribution of Lower Jurassic carbonate units of (based on Duarte et al., 2010) and the location of the Peniche section.

\section{The Lower Jurassic in the Lusitanian Basin}

The LB is a narrow, small north-south-trending elongated basin limited to the west by the Variscan (granitic and metamorphic) Berlenga Horst (e.g., Wilson et al., 1989; Kullberg et al., 2013) and to the east by the Porto-Tomar shear zone (Fig. 1). This basin had its origin in the Triassic and was the result of the extensional phase that preceded the genesis of the North and Central Atlantic Ocean (e.g., Wilson et al., 1989). In the western portion of the Hesperian Massif, this extensional phase was represented by the formation of half-grabens, originally filled by a thick siliciclastic series of continental deposits (Silves Group; e.g., Kullberg et al., 2013).

In the LB, the Lower Jurassic generically corresponds to shallow- to deeper-marine carbonate deposits (Soares et al., 1993; Azerêdo et al., 2003). The base of the Jurassic is marked by a fine-grained, mainly siliciclastic, sedimentation with some dolomitic and evaporitic intercalations (the Pereiros and Dagorda formations). These units are of Hettangian age and show a typical set of lagoonal environments controlled by arid climate conditions. These Hettangian facies are capped by the Coimbra Formation (Fm) (Sinemurian), which is the first true carbonate unit represented at a basinal scale.



Fig. 2 - Simplified geological map of the Peniche Peninsula (modified from Camarate França et al., 1960) showing the locations of the main stops of this field-trip.

The Coimbra Fm is composed of a succession of dolostones and limestones, with the latter lithotype being more extensively expressed at the top of the unit and in its westernmost sectors, corresponding to a marginal-marine palaeoenvironmental setting. In the upper Sinemurian, located in the western part of the basin, the deposits are characterized by an organic-matter-rich marl-limestone series with ammonites 


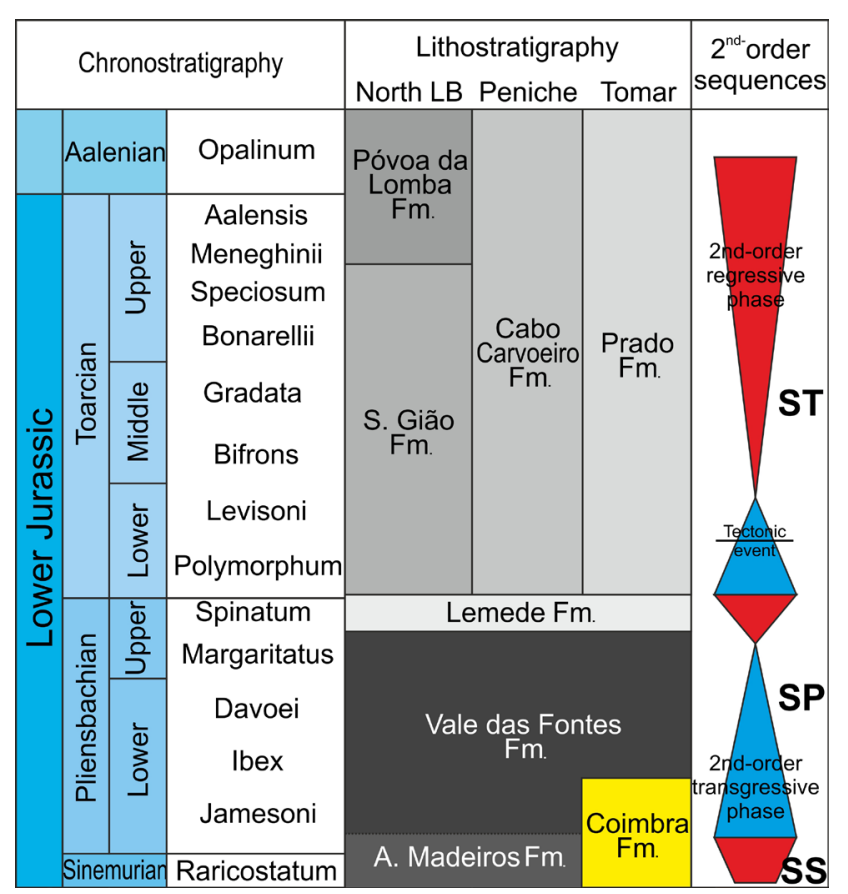

Fig. 3 - Stratigraphic chart for the upper Sinemurian-lower Aalenian succession in great part of the LB (modified from Duarte, 2007) and incorporating new biostratigraphic data from Comas-Rengifo et al., 2013).

(Água de Madeiros Fm) that mark the onset of the development of open-marine conditions in the basin. This fine-grained sedimentation extends throughout the basin in the lower Pliensbachian-upper Toarcian interval, corresponding to the Vale das Fontes, Lemede, S. Gião, and Póvoa da Lomba formations (Fig. 3; Duarte \& Soares, 2002). The ammonites and calcareous nannofossils recorded in these units allow a closely constrained biostratigraphic control of the series to be achieved (e.g., Phelps, 1985; Elmi, 2006; Perilli \& Duarte, 2006; Mouterde et al., 2007; Rocha, 2007; Oliveira et al., 2007; Silva et al., 2011b; Silva, 2013; Comas-Rengifo et al., 2013; Mattioli et al., 2013; Paredes et al., 2013). The weak lateral facies variation observed across the basin suggests that these sediments were deposited in a marine carbonate ramp system dipping towards the west to northwest and controlled by N-S- and NE-SW-oriented tectonic trends (Duarte, 2007). Despite the general hemipelagic sedimentation, some particular sedimentary aspects can be recognized at several locations in the southern half of the LB, such as Tomar (Prado Fm) and Peniche (Cabo Carvoeiro Fm) (Duarte \& Soares, 2002) (Figs 1 and 3). In this latter locality, the deposition of siliciclastic and redeposited oolitic sediments during the Toarcian confirm a palaeogeography controlled by the uplift of the western igneous Berlenga block (e.g., Wright \& Wilson, 1984; Duarte, 1997; Duarte et al., 2004).

\section{Stop 1. The Lower Jurassic succession at}

Peniche (L. V. Duarte, R. L. Silva, M. J. Comas-

Rengifo $^{2} \&$ R. B. Rocha)

The perimeter of the Peniche peninsula exhibits a succession of sedimentary carbonate rocks, consisting of marls, locally organic-rich, and marly, micritic, dolomitic, bioclastic, oolitic, oncolitic, and sandy limestones. These deposits belong to the Coimbra, Água de Madeiros, Vale das Fontes, Lemede, and Cabo Carvoeiro formations (Figs 3 and 4). The latter three units have their type-sections in this location (Duarte \& Soares, 2002). In addition, given the very specific geological features, coupled with an inferred turbiditic sedimentation that evolves into peri-marginal environments (see Wright \& Wilson, 1984; Duarte, 1997), the Cabo Carvoeiro Fm is exclusive to the Peniche area. The whole succession presents a thickness of more than $450 \mathrm{~m}$.

The entire series is paleontologically very rich in nektonic (ammonites and belemnites) and benthonic (including brachiopods, bivalves, gastropods, crinoids, echinoderms, and corals) macrofauna and various types of trace fossils. The ammonites, present throughout the upper Sinemurian (Raricostatum Zone) to middle Toarcian (Gradata Zone) (e.g., Mouterde, 1955; Phelps, 1985; Dommergues, 1987; Mouterde et al., 2007), allow a detailed biostratigraphic zonation to be made, in some cases at the subzone scale. Recent biostratigraphic data have allowed aspects of the Sinemurian and Pliensbachian succession to be revealed in detail (see Silva et al., 2011b; Paredes et al., 2013; Silva, 2013). Intra- and extra-basinal correlations are also established on the basis of calcareous nannofossil biostratigraphy for the Pliensbachian-Toarcian interval at Peniche (Mattioli et al., 2013).

Five lithostratigraphic units are recognized in the Peniche peninsula area (based on Duarte \& Soares, 2002; Duarte, 2007), as follows (Fig. 4).

The Coimbra Fm is the oldest unit observed in Peniche, being Sinemurian in age, and displays a succession of micritic, bioclastic, oncolitic, and oolitic limestones with very rare intercalations of marly levels (Fig. 5A). Several facies are bioturbated (Thalassinoides) and rich in bivalves and gastropods. The formation is around $50 \mathrm{~m}$ thick.

The Água de Madeiros Fm consists of a sequence of calcareous and/or laminated marls, with

${ }^{2}$ Departamento de Paleontología, Facultad de Ciencias Geológicas, Univ. Complutense de Madrid. Madrid, Spain. 


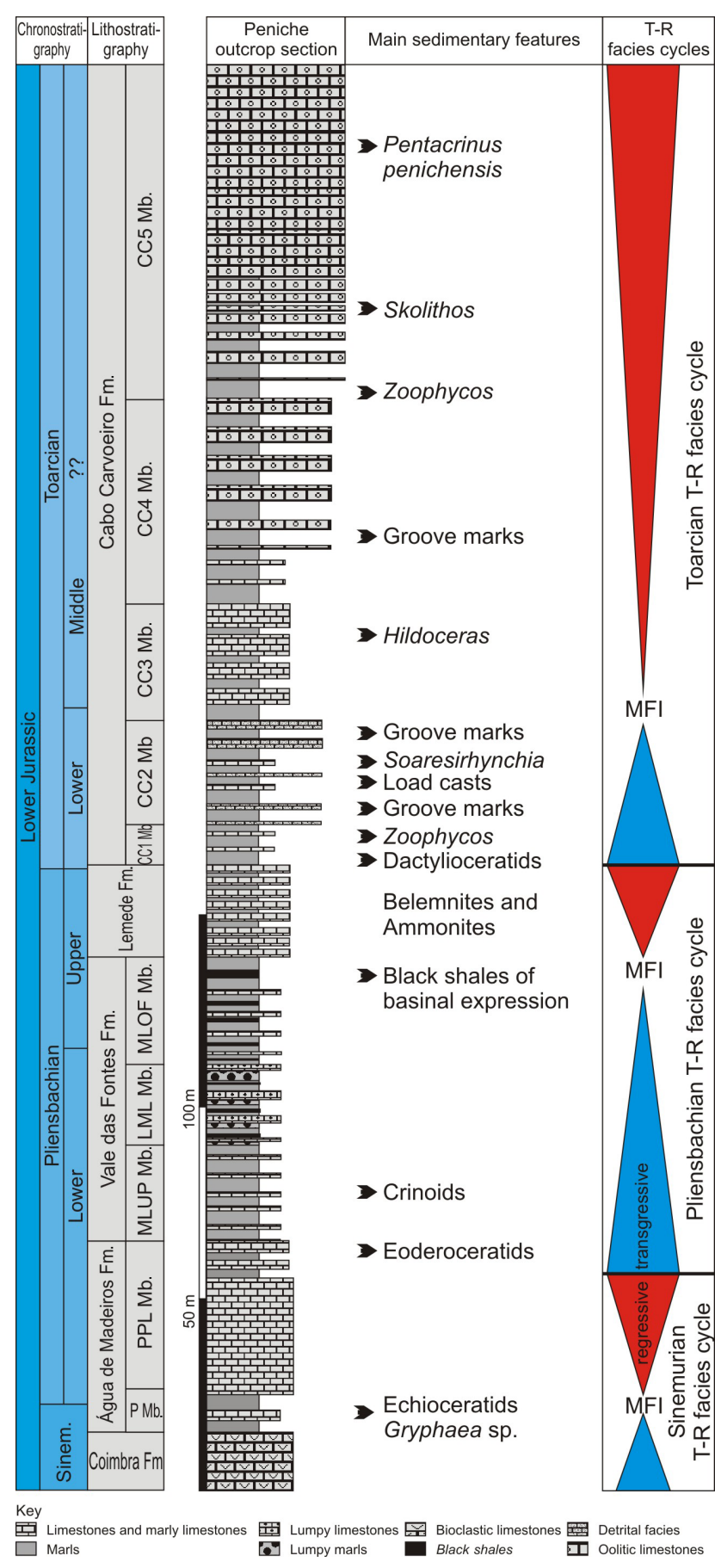

Fig. 4 - Stratigraphic chart of the Sinemurian-Aalenian (?) succession of Peniche (modified from Duarte et al., 2004; Duarte, 2007; includes the new biostratigraphic data from Paredes et al., 2013).

some horizons rich in organic matter, and marly, micritic, and bioclastic limestones. The formation is divided into the Polvoeira and Praia da Pedra Lisa members, which have thickneses at Peniche of 10 and $\sim 40-50 \mathrm{~m}$, respectively. The former member corresponds to a sequence of alternating marl and marly limestones, slightly bioclastic and very rich in nektonic (ammonites and belemnites) and benthonic macrofauna (mainly brachiopods and bivalves) (Fig.
5A). The Polvoeira member also includes the ichnogenera Diplocraterion, Thalassinoides, and Rhizocorallium. The Praia da Pedra Lisa member $(\mathrm{Mb})$ is dominantly calcareous and comprises mainly bioclastic facies. The intense fracturing hinders a more detailed analysis to be made. Ammonite data constrain the base of the Água de Madeiros Fm to the top of the Raricostatum Zone-base of the Jamesoni Zone (Paredes et al., 2013).

The Vale das Fontes Fm is dated as ranging from the base of the Jamesoni Zone to the upper Margaritatus Zone and marks the return to marly-limestone sedimentation, with some horizons being enriched in organic matter (Fig. 5B). At Peniche, this unit has a thickness of around $76 \mathrm{~m}$ and is subdivided into three informal members: The marls and limestones with Uptonia and Pentacrinus (MLUP) mb, the lumpy marls and limestones (LML) mb, and the marly limestones with organic-rich facies (MLOF) mb.

MLUP mb (25 m; Jamesoni Zone): alternations of bioturbated decimeter-scale marl and centimetre-thick marly limestone with nektonic and benthonic macrofauna (crinoids, brachiopods, and bivalves).

LML mb (21 m; Jamesoni Zone to Ibex Zone): defined by the occurrence of lumpy facies interbedded with a marl-limestone succession with rare organic-rich facies (Fig. 5C). Benthic macrofauna are scarce, but ammonites and belemnites are present throughout. The lumps consist of micritic lumpy concretions, generally subspherical shaped and reaching several centimeters in size (Fig. 5D) and which are apparently related to microbial activity (e.g., Dromart \& Elmi, 1986; Elmi et al. 1988; Fernández-López et al., 2000).

MLOF mb (30 m; uppermost Ibex Zone-upper Margaritatus Zone; Silva et al., 2011b; Silva, 2013): this member is differentiated from the framing units by an increase in the marly and organic matter character of the series, locally with diverse and abundant small benthonic macrofauna (crinoids, brachiopods, bivalves, and gastropods), ammonites, and belemnites.

The Lemede Fm has a thickness of around 23 $\mathrm{m}$ and displays a predominantly limestone character with an abundance of belemnites and ammonites (Fig. 5E). The base of this unit is assigned to the uppermost Margaritatus Zone (Silva et al., 2011; Silva, 2013). The top of the unit corresponds to the extreme base of the Toarcian (Polymorphum Zone, Mirabile Subzone).

The Cabo Carvoeiro Fm is exclusive to Peniche and has its own special features marked by the occur- 



Fig. 5 - Some sedimentological and stratigraphic features of the Lower Jurassic deposits at Peniche. A - Intra-Sinemurian discontinuity (dotted line) between Coimbra and Água de Madeiros formations at Peniche. B - General view over part of the Vale das Fontes Fm in Portinho da Areia do Norte. C - General view of LML mb at Portinho da Areia do Norte beach. D - Detail of lumps in the LML mb of Vale das Fontes Fm. E - General view of the Lemede Fm showing the cyclicity of the limestone-marl alternations. F - Subarkosic facies of the $\mathrm{CC} 2 \mathrm{mb}$ in the Abalo beach. G - General view of the calciclastic limestone-marl alternations of the CC4 mb at Baixa do Outeiro. H - Calciclastic and siliciclastic facies and stratonomy of the CC5 mb at Carvoeiro Cap. 
rence of a set of detrital (Fig. 5F), oolitic, and bioclastic facies (see Wright \& Wilson, 1984; Duarte, 1997). According to Duarte \& Soares (2002), this formation is subdivided into the following five members:

The CC1 mb (11 m; Polymorphum Zone, Semicelatum Subzone): corresponds to a predominantly grey marly unit with some intercalations of marly limestones (biomicrites/wackestones). This unit is very fossiliferous, including ammonites, belemnites, tiny brachiopods, bivalves and Zoophycos.

The CC2 mb (25 m; Levisoni Zone): corresponds to a marly dominated succession, poor in macrofauna (only ammonites and some brachiopods), and presents several lenticular siliciclastic facies and wood fragments. The lithofacies are very diversified, from greyish marls and limestones to subarkosic microconglomerates (Fig. 5F). The siliciclastic facies, with variable thickness $(\leq 75 \mathrm{~cm})$ and erosional structures like groove marks and load casts show typical turbidite features (e.g., Wright \& Wilson, 1984).

The CCC3 mb (30 m thick; Levisoni-Bifrons zones): marks the disappearance of the siliciclastic facies. This unit corresponds to a monotonous marl/ limestone alternation with an increase of the calcareous components towards the top. These beds show strong bioturbation (sometimes, Chondrites), abundant ammonites but the macrobenthonic record is scarce.

The CC4 mb (54 m; Bifrons Zone-Bonarellii? Zone): despite the marly nature of the base, this member is characterized by the occurrence of centimetric to decimetric grainstones (oosparites and oopelsparites) levels with some grey-greenish marly facies (Fig. 5G). The base of grainstone facies is generally sharp and frequently shows groove and tool marks. The top surfaces are very irregular and, sometimes, bioturbated (including Skolithos).

The CC5 mb (>90 m; Speciosum? Zone-Aalenian): tends to be similar to the $\mathrm{CC} 4 \mathrm{mb}$, although without the marly levels and with an observable increase in bed thickness and siliciclastic character (quartz particles) (Fig. 5H). In some levels, the paleontological associations, rich in bivalves, gastropods, crinoids (Pentacrinus penichensis) and ahermatipic corals, indicate that deposition took place in a shallow-water palaeoenvironment.

The vertical analysis of the different units cropping out in the Peniche Peninsula allows three third-order transgressive-regressive facies cycles to be recognized (see Duarte et al., 2004, 2010; Duarte, 2007) (Fig. 4).
4. Stop 2. Sedimentary and palaeoenvironmental constrains on the Pliensbachian organic-rich deposition in the Lusitanian Basin (Ricardo L. Silva \& L. V. Duarte)

\subsection{Introduction}

One of the main characteristics of the Pliensbachian series of the LB is the occurrence of several organic-rich intervals (e.g., Duarte et al., 2010; Silva et al., 2011b, 2012; Silva, 2013). The first main step in the characterization of the organic-rich facies of this unit was achieved by the work of Oliveira et al. (2006), where the authors present the geochemical characterization of this time interval in the reference section of Peniche, based on total organic carbon (TOC), Rock-Eval pyrolysis and biomarkers. Afterwards, Duarte et al. (2010), based in a detailed biostratigraphic framework (especially complete in the Peniche section), sedimentological data and TOC variation, present a consolidated $2^{\text {nd }}$-order transgressive-regressive facies cycles scheme for the Lower Jurassic carbonate series of the LB and compared them with those observed in the Basque-Cantabrian neighbouring basin. Nowadays, these organic-rich levels are intensively studied throughout the basin, using several innovative techniques, including conventional isotope geochemistry in kerogen (Silva et al., 2011b), biogeochemistry (Silva et al., 2012), outcrop gamma-ray spectrometry (Correia et al., 2012), biomarkers and palynofacies (e.g., Ferreira et al., 2010; Silva et al., 2010, 2011a).

\subsection{The MLOF MB: characterization and regional framing}

At Peniche, the MLOF mb crops out in the Portinho da Areia do Norte beach (UTM coordinates 29 S, 467389m; 4357730m) (Fig. 2). In this sector this unit is characterized by the pervasive occurrence of organic-rich facies, including several black shales (e.g., Oliveira et al., 2006; Duarte et al., 2010; Silva et al., 2011b, 2012; Silva, 2013).

The first metres of the series, corresponding to the Ibex Zone, are composed of regular marl-limestone alternations, grading to a more irregular marl-dominated interval dated from the Davoei Zone (Fig. 6). The limit with the LML mb is sharp and marked by the disappearance of the lumpy facies. At the beginning of the late Pliensbachian, the more regular marl-limestone alternations resume, persisting until the limit with the Lemede Fm.

A very precise biostratigraphic control of the MLOF 
$\mathrm{mb}$ at a basin wide scale is attained in this section. The ammonites allow a detailed biostratigraphic zonation (Mouterde, 1955; Phelps, 1985; Mouterde et al., 2007; Rocha et al., 2013) reinforced by additional new data from recent ammonite collection campaigns (see, for example, Silva et al., 2011b; Silva, 2013) (Figs 6 and 7A). The newly collected bed-by-bed ammonite data are, at a broader scale, in good agreement with the biozonation charts established for the Pliensbachian of the LB.

Nevertheless, these data allowed improving of some biostratigraphic boundaries. The main one is related with the age of the Lemede Fm, which was pre- viously assigned to the Emaciatum (Spinatum) Zone (e.g., Mouterde, 1955; Duarte \& Soares, 2002) (Fig. 6). The new high-resolution biostratigraphic data reveal that the base of this formation corresponds to the Margaritatus Zone, uppermost Gibbosus Subzone, with a distinct level of Arieticeras gr. algovianum occurrence found approximately $4 \mathrm{~m}$ above the base of this unit (Silva et al., 2011b; Silva, 2013).

Based on sedimentological criteria, it is possible to distinguish three main sedimentation domains in MLOF mb (Silva et al., 2012; Silva, 2013), relating to different environmental subdivisions as predicted



Fig. 6 - Detailed log of the MLOF mb and base of Lemede Fm in the Peniche reference section of the LB (modified from Silva et al., 2011b; Silva, 2013). 
for carbonate ramp systems (see Burchette \& Wright, 1992 and references therein). Westwards, corresponding to Peniche and S. Pedro de Moel sections and Figueira da Foz sector, the main feature of the MLOF $\mathrm{mb}$ is its richness in organic-matter (Silva et al., 2011a, 2011b, 2012; Silva, 2013). Palaeobathimetric estimates based in microfossil data suggest that water column thickness averaged around 100200 metres (e.g., N'zaba-Makaya et al., 2003). The central-eastern domain, namely at Rabaçal, is distinguished by the significant occurrence of nautiloids and the widespread presence of usually small mud-wacke-packstone carbonate build-ups. Locally, organic-rich facies are observed, although these are not that relevant when compared with the Western domain. The Tomar facies, in the Southeastern domain (Fig. 1), represents the shallowest of the studied environments.

\subsection{Organic-rich facies: origin, preservation and palaeoenvironmental constrains}

The organic-rich facies of the MLOF mb vary between massive dark marls to true black shales (see Duarte et al., 2010; Silva et al., 2011b, 2012; Silva, 2013). The former are often bioturbated and macrofauna is rarely present. The black shales usually have a net laminated base, sometimes non-bioturbated over a few centimetres. Generally, they grade upwards to a more bioturbated (mainly Phymatoderma and Chondrites) calcareous facies where benthonic and nektonic macrofauna is abundant (Silva, 2013). From the analysis of the TOC vertical variation, Duarte et al. (2010 and references therein) defined three main organic-rich intervals, dated from the Davoei and Margaritatus zones, which present, at Peniche, maximum TOC values of 12,15 and $15 \%$, respectively.

The palynofacies analysis and the study of the origin-related biomarkers show that the organic matter of this interval consists in a variable mixture of marine and continental components, preserved in a marine environment and under variable redox conditions (e.g., Ferreira et al., 2010; Silva et al., 2012) (Fig. 7B and C).

Carbonate and kerogen carbon isotopic data obtained in the Peniche section (Silva et al., 2011b) allow demonstrating a relationship between an episode of accumulation and preservation of organic matter in the LB and a global perturbation of the carbon cycle (e.g., Jenkyns \& Clayton, 1986). Comparing the geological record of the LB with several others worldwide, Silva et al. (2011b) suggested that the
Pliensbachian interval was characterized by several well constrained episodes (at least of regional extension) of deposition and preservation of organic matter (the late Pliensbachian Organic Matter Preservation Interval), which, interestingly, preceded the T-OAE (e.g., Hesselbo et al., 2007).

Biogeochemical studies performed across the basin show that carbohydrates and proteins are present in low concentrations, reaching up to 385.13 and 451.13 $\mu \mathrm{g} / \mathrm{g}$ rock, respectively (Fig. 7D). The main variations are observed in the lipid contents, ranging from 197.67 to $8446.36 \mu \mathrm{g} / \mathrm{g}$ rock, reached at Peniche. The samples with the highest amounts of lipids seem to correlate with low $\left[\mathrm{O}_{2}\right]$ time intervals, suggesting selective lipid preservation under oxygen depleted and hydrogen sulfide-rich environments (Silva et al., 2012).

\section{Stop 3. The Pliensbachian-Toarcian boundary at Ponta do Trovão (R. B. Rocha)}

The Global Stratotype Section and Point (GSSP) for the lower boundary of Toarcian Stage was recently proposed at the base of micritic limestone bed $15 \mathrm{e}$ at Ponta do Trovão (39 $22^{\prime} 15^{\prime}$ 'N , 9'23'07' $\left.\mathrm{W}\right)$, in the topmost part of the Lemede Fm and marked by the first appearance of several species of Dactylioceras (Eodactylites) sp. (see Elmi, 2006; Rocha, 2007; Rocha et al., 2013). The uppermost part (around 1m thick) of this unit, as well as the stratigraphic distribution of ammonite taxa, were described by Choffat (1880) and Mouterde (1955) as a particular unit named Couches de passage (Transition beds). These have yielded a continuous and diversified fossil record and have been intensively sampled. Shells are commonly concentrated, forming irregular heaps. Plicatula and serpulids are fixed on ammonite shells or casts. Because of these features, the Couches de passage are interpreted as being deposited under a low sedimentation rate regime although hiatuses did not occur. The highest bed (15e) has yielded a characteristic association of dactylioceratids that is classically interpreted as marking the beginning of the Toarcian. The detailed description of the Couches de passage succession is presented here, from the bottom to the top (Elmi et al., in Rocha, 2007) (Figs 8 and 9):

Emaciatum/Spinatum Zone, Elisa/Hawskerense Subzone

Bed 15a $(0.15 \mathrm{~m})$ - It corresponds to the Canavaria bed. Bioturbated, micritic limestone with some irregular nodular lumps. Canavaria zancleana (Fucini) is associated with Emaciaticeras emaciatum (Catullo), E. 



Fig. 7 - A - Base of the MLOF mb and biostratigraphy (in Silva, 2013). B - Palynofacies sample evidencing the dominance of marine Amorphous Organic Matter (AOM) (modified from Silva et al., 2012). C - Amorphous Organic Matter-Phytoclasts-Palynomorphs ternary plot for part of the Pliensbachian series at Peniche (modified from Ferreira et al., 2010). D - Lateral and temporal variation of the lipids content in the Rabaçal, Peniche and S. Pedro de Moel outcrop sections (modified from Silva et al., 2012).



Fig. 8 - Detail of the Couches de passage (levels 15a-15e) at the top of the Lemede Fm (level 15e). The boundary between 15d and 15 e marks the Pliensbachian-Toarcian boundary at Ponta do Trovão (Peniche). 


\section{Lithology \\ (as published in \\ Duarte and Soares 2002, \\ Hesselbo et al. 2007)}

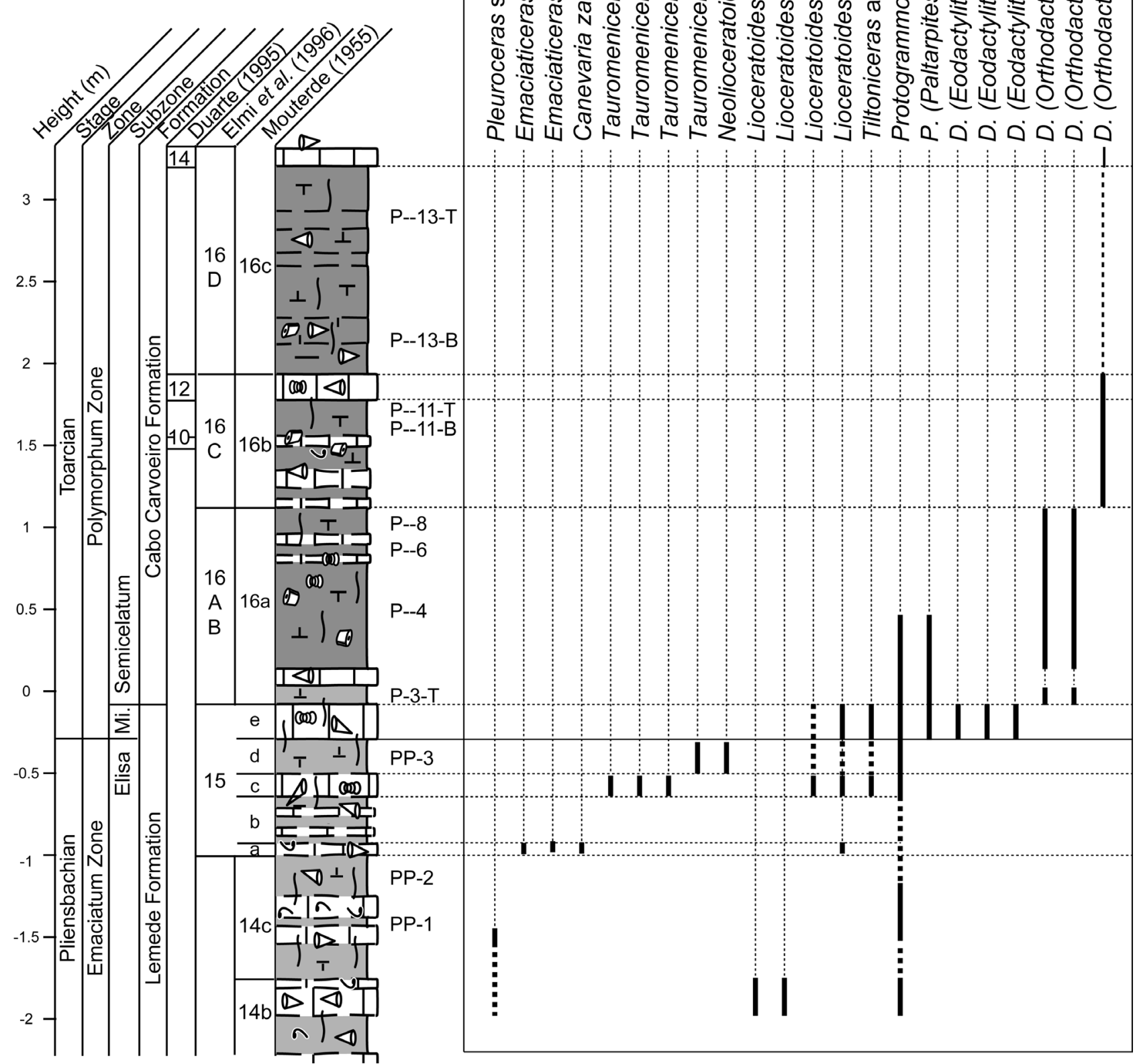

Fig. 9 - Detailed ammonite record across the Pliensbachian-Toarcian boundary at Ponta do Trovão (Peniche) (after Elmi et al. 1996; Elmi et al., in Rocha, 2007; Rocha et al., 2013; modified).

lotti (Fucini) and Lioceratoides aff. ballinense (Haas).

Bed 15b $(0.25 / 0.30 \mathrm{~m})$ - Calcareous laminated marls with brachiopods (Zeilleria sp.), belemnites, gastropods and bivalves [Plicatula (P.) spinosa (Sowerby) var. pectinoides (Lamarck)].

Bed 15c $(0.25 / 0.30 \mathrm{~m})$ - It is also known as the Tauromeniceras bed. It is formed of bioturbated mic- ritic limestones, with Tauromeniceras elisa (Fucini), T. disputandum Dubar, T. gr. nerina (Fucini), Lioceratoides aradasi (Fucini), L. aff. ballinense (Haas), Tiltoniceras aff. capillatum (Denckmann), Protogrammoceras (Paltarpites) sp., Spiriferina gr. rostrata Schlotheim and $P$. (P.) spinosa var. pectinoides (Lamarck). 
Bed 15d (0.20/0.30 m) - It corresponds to a marly limestone enriched in belemnites and spiriferinids. Tauromeniceras mazetieri (Dubar), Neolioceratoides aff. hoffmanni (Gemmellaro), Spiriferina gr. rostrata Schlot., Zeilleria sp. and P. (P.) spinosa var. pectinoides (Lam.) are commonly recorded taxa.

Polymorphum/Tenuicostatum Zone, Mirabile/ Paltum Subzone
Bed 15e $(0.20 \mathrm{~m})$ - This corresponds to the Eodactylites bed, composed of micritic limestone bearing numerous ammonites, many of those occurring at the top of the bed. Ammonites generally correspond to oxidized-pyrite internal moulds. Eodactylites are abundant and diversified: Dactylioceras (Eodactylites) simplex (Fucini), D. (E.) pseudocommune Fuc., $D$. (E.) polymorphum Fuc. The association of $D$. (O.)

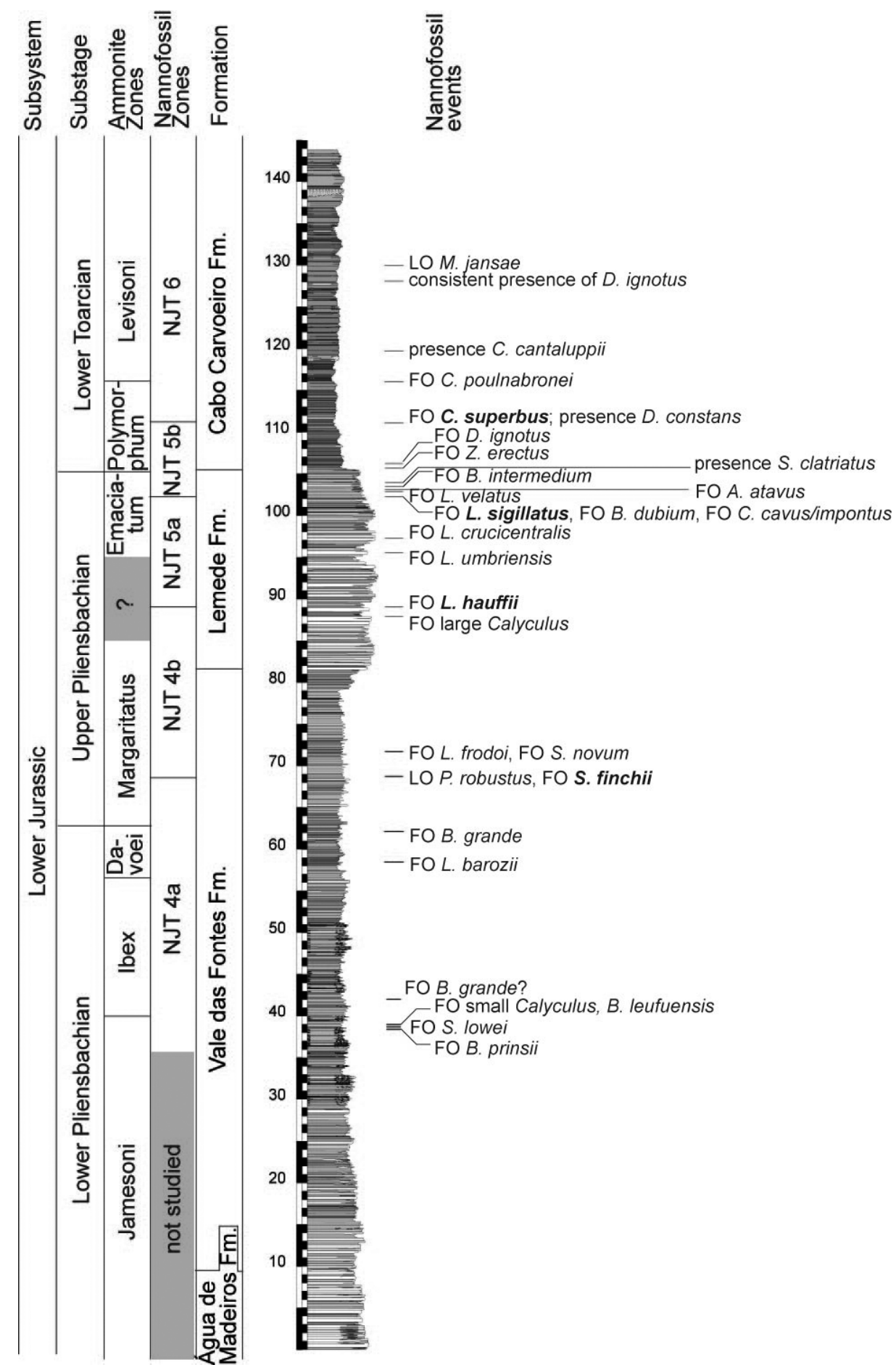

Fig. 10 - Stratigraphic positions of calcareous nannofossil events, both first occurrence (FO) and last occurrence (LO) in the Pliensbachian to lower Toarcian interval of the Peniche section. 



Fig. 11 - Comparison of carbon isotope record and the succession of calcareous nannofossil events of the Peniche section with Amellago (Morocco; Bodin et al., 2011) and Valdorbia [central Italy; isotope data from Sabatino et al. (2009); nannofossil biostratigraphy was previously established by Reale et al. (1992); the same samples as Sabatino et al. (2009) were re-studied by E.M., unpublished data].

simplex with $D$. (O.) pseudocommune may indicate a slight condensation, compared to data from the Iberian Ranges. This interpretation, however, requires further confirmation from data collected in other areas. Other ammonites recorded in the Eodactylites bed testify the survival of late Pliensbachian specimens, such as Tiltoniceras aff. capillatum (Denck.) and Lioceratoides aff. ballinense (Haas). The presence of Protogrammoceras (Paltarpites) cf. paltum (Buck.) in this bed is especially important for correlations with NW Europe. Brachiopods (Spiriferina sp., Zeilleria sp. and Rhynchonella sp.), belemnites and bivalves $[P$. (P.) spinosa var. pectinoides (Lam.)] are also common. This bed marks the beginning of the Toarcian (Mirabile/Paltum Subzone of the Polymorphum/Tenuicostatum Zone).

Polymorphum/Tenuicostatum Zone, Semicelatum Subzone

Bed 16a $(1.70 \mathrm{~m})$ - Bed 16 marks the lower part of the Cabo Carvoeiro Fm. The lowest two metres of this marl-dominated unit contain small pyritized internal moulds of specimens attributed to NW European species of Orthodactylites namely, D. (O.) crosbeyi (Simpson), D. (O.) clevelandicum Howarth, associated with Protogrammoceras (Paltarpites) sp. The record of these specimens allows a tentative correlation with the Crosbeyi/Clevelandicum Subzone of Britain, and supports the hypothesis that the absence of Eodactylites in many classic NW European sections is due to a sedimentatary gap, rather than to a palaeogeographical controlled distribution of this genus. This bed also yields an abundant assemblage of belemnites, gastropods and brachiopods. Bioturbation is widespread (Zoophycos and pyritised tubular burrows). The upper part of Bed 16 contains several fossiliferous layers yielding mainly $D$. (O.) semice- latum (Simpson). These ammonites are commonly found in random orientation, probably as a result of bioturbation.

\section{Stop 4. The early Toarcian anoxic event (E. Mattioli, B. Pittet ${ }^{1} \&$ G. Suan ${ }^{1}$ )}

\subsection{Calcareous nannofossil stratigraphy}

Several nannofossil events, both first (FO) and last occurrences (LO), characterize the Pliensbachian and the lower Toarcian interval and allow the recognition of three nannofossil zones (NJT 4 to NJT 6) and four subzones (Fig. 10). Concerning the uppermost Pliensbachian-lower Toarcian interval, the FOs of $L$. crucicentralis and of L. velatus in the upper part of the Emaciatum Zone are of particular interest as these two species were previously reported from the lower Toarcian (Bown \& Cooper, 1998; Mattioli \& Erba, 1999; Mattioli et al., 2008). It is worth to notice that the oldest recorded L. velatus have all the diagnostic characters described by Bown \& Cooper (1989), but are slightly smaller in size and the rim is thinner.

Another intriguing biostratigraphic pattern of the Peniche section is the FO of D. ignotus at the base of the Polymorphum Zone, basal Toarcian, whilst in previous works this event was noticed in the upper part of the lower Toarcian (Bown, 1987; Mattioli \& Erba, 1999; Mattioli et al., 2004, 2008). In the Amellago section, Morocco (Bodin et al., 2010) and in Valdorbia section, Central Italy (personal observation), D. ignotus is similarly first recorded in the basal Toarcian (Fig. 11). A possible explanation of this discrepancy is due to the fact that the basal Toarcian sediments are often very condensed or lacking due to hiatuses occurring in many Western Tethyan areas,

${ }^{1}$ Univ. Lyon, Université Claude Bernar Lyon 1, ENS de Lyon, CNRS, UMR 5276 LGL-TPE, F-69622 Villeurbanne, France 
(Wignall, 1991; Morard et al., 2003; Röhl \& SchmidRöhl, 2005; Léonide et al., 2012), but not in Peniche and Amellago. Furthermore, D. ignotus behave as a Lazarus species being absent from the sediments corresponding to the T-OAE in Peniche and Amellago. The consistent occurrence of D. ignotus is then recorded by the end of the T-OAE (Fig. 11).

Useful nannofossil events are: the FO of $D$. ignotus that occurs at the end of the Pliensbachian/Toarcian Carbon Isotope Event (PT-CIE), the FO of C. superbus that characterizes the positive carbon isotope rebound between the two main negative CIEs during the Pliensbachian/Toarcian and during the early Toarcian, and the LO of $M$. jansae that marks the end of the early Toarcian CIE.

\subsection{Duration of the early Toarcian CIE}

Spectral analysis of a dataset generated from the sedimentary record (wt.\% $\mathrm{CaCO}_{3}$ ) of the hemipelagic section of Peniche allowed Suan et al. (2008b) to establish a cyclostratigraphic calibration of the early Toarcian interval. A duration of $\geq 1.9 \mathrm{Myr}$ for the early Toarcian was estimated and of $\sim 900 \mathrm{kyr}$ for the entire carbon isotope excursion (Fig. 12). The shift to- wards lower carbon isotope values occurred in $\sim 150$ $\mathrm{kyr}$, and carbon isotope values remained low for $\sim 450$ kyr; the subsequent increase of carbon isotope values lasted $\sim 300$ kyr. These results, although challenged by Kemp et al. (2011), were used in the recent Geological Timescale of Gradstein et al. (2012). Suan et al. (2008b) show that the OAE records a transition from eccentricity/precession dominated sedimentary cycles to eccentricity/obliquity cycles, suggesting that the Toarcian event was accompanied by a fundamental change in heat redistribution on the Earth's surface that made the obliquity signal, normally better recorded at high latitudes, giving the pace for the formation of short-term sedimentary cycles at low latitudes. This cyclostratigraphic calibration of the CIE implies a long-lasting carbon release and supports the hypothesis of a long-lasting $\mathrm{CO}_{2}$ degassing, most likely related to the emplacement of the large igneous province of Karoo-Ferrar as the main cause of the Toarcian CIE. Suan et al. (2008b) results also indicate that abrupt and cyclical negative shifts in $\delta^{13} \mathrm{C}$ took place in less than $20 \mathrm{kyr}$ at the onset of the CIE, suggesting that orbitally-paced pulses of carbon release may have occurred at the base of the CIE. A combination of two processes may then explain the



Fig. 12 - Comparison between the high-resolution TOC and carbon isotope curve (Hesselbo et al., 2007), oxygen isotopes measured on brachiopod calcite, nannofossil absolute abundance and Schizosphaerella size (Suan et al., 2008a). 
development and duration of the CIE, involving brief pulses of gas hydrate destabilisation in the early phases of Karoo-Ferrar eruption followed by long-lasting release of isotopically light carbon via volcanism.

\subsection{Palaeoenvironmental changes during the early Toarcian CIE: evidence from calcareous nannofossils}

A quantification of nannofossil size and absolute abundance performed on the upper Pliensbachianlower Toarcian marl-limestone alternations of the Peniche section (Fig. 12) reveals that calcareous nannofossil abundance per gram of rock is very high in the uppermost Pliensbachian and lowermost Toarcian but values are drastically lower in the interval of rock corresponding to the T-OAE (Mattioli et al., 2008, 2009; Suan et al., 2008a, 2010). The size of Schizosphaerella (incertae sedis), a major carbonate producer during the Jurassic, shows the highest values in the uppermost Pliensbachian, with lower values in the interval corresponding to the CIE of the PliensbachianToarcian boundary. A size recovery occurs in the basal Toarcian, with a second, more drastic decrease in the negative carbon isotope excursion recorded in the lower Toarcian (Fig. 12). Coeval shifts to lower values of brachiopod oxygen isotope compositions and closely correlated northward migrations of Mediterranean ammonite fauna suggest that both $\mathrm{C}$ isotope negative excursions and Schizosphaerella size decreases coincided with major rises in seawater temperatures (Suan et al., 2008a). The results of Suan et al. (2008a, 2010) and Mattioli et al. $(2008,2009)$ indicate that these two excursions occurred synchronously with significant carbonate production crises in both neritic and pelagic domains, as suggested by concomitant decreases in platform-derived carbonate mud and dramatic reductions in the size of the main pelagic carbonate-producer Schizosphaerella. These data are best explained by two distinct phases of massive release of isotopically light $\mathrm{CO}_{2}$ and enhanced greenhouse conditions, which in turn affected the calcification potential and trophic levels of both pelagic and neritic systems.

\section{Acknowledgments}

This work has been supported by the Project PTDC/CTEGIX/098968/2008 (FCT/MEC, COMPETE-FEDER).

\section{References}

Azerêdo A. C., Duarte L. V., Henriques M. H. \& Manuppella G. (2003) - Da dinâmica continental no Triásico aos Mares do Jurássico Inferior e Médio. Cadernos Geol. Portugal, Inst. Geol. Min., 43 p.
Bown P. R. (1987) - Taxonomy, evolution, and biostratigraphy of Late Triassic-Early Jurassic calcareous nannofossils. Spec. Pap. Palaeontol. 38, 1-118.

Bown P. R. \& Cooper M. K. (1989) - New calcareous nannofossil taxa from the Jurassic. J. Micropal. 8, 91-96.

(1998) - Jurassic. In: Bown P. R. (Ed.), Calcareous Nannofossil Biostratigraphy, British Micropal. Soc. Series. Chapman and Hall/Kluwer Acad. Publish., London, 86131. DOI: $\underline{10.1144 / \mathrm{jm} .8 .1 .91}$

Burchette T. P. \& Wright V. P. (1992) - Carbonate ramp depositional systems. Sediment. Geol. 79, 3-57. DOI: 10.1016/0037-0738(92)90003-A

Camarate França J., Zbyszewski G. \& Almeida F. M. (1960) Carta geológica de Portugal, na escala 1/50 000. Notícia Explicativa da folha 26-C (Peniche). Serv. Geol. Port., 33 p.

Choffat P. (1880) - Étude stratigraphique et paléontologique des terrains jurassiques du Portugal. Première livraison. Le Lias et le Dogger au Nord du Tage. Mem. Secção Trab. Geol. Port. XIII+79 p.

Comas-Rengifo M. J., Duarte L. V., Goy A., Paredes R. \& Silva R. L. (2013) - El Sinemuriense superior (Cronozonas Oxynotum y Raricostatum) en la región de S. Pedro de Moel (Cuenca Lusitánica, Portugal). Com. Geológicas 100, fasc. esp. I, 15-19. http://www.lneg.pt/download/6612/2_ART CG13_ESPECIAL_I_FINAL2_corr3.pdf

Correia G. G, Duarte L. V., Pereira A. \& Silva R. L. (2012) Outcrop gamma-ray spectrometry: Applications to the Sinemurian-Pliensbachian organic-rich facies of the Lusitanian Basin (Portugal). J. Iberian Geol. 38 (2), 373-388. DOI: 10.5209/rev_JIGE.2012.v38.n2.40464

Dommergues J.-L. (1987) - L'évolution chez les Ammonitina du Lias Moyen (Carixien, Domérien basal) en Europe occidentale. Doc. Lab. Géol. Lyon 98, 1-297.

Dromart G. \& Elmi S. (1986) - Développement de structures cryptalgaires en domaine pélagique au cours de l'ouverture des bassins jurassiques (Atlantique central, Téthys occidentale). C. R. Acad. Sc. Paris 303 (4), sér. II, 311-316.

Duarte L. V. (1997) - Facies analysis and sequential evolution of the Toarcian-Lower Aalenian series in the Lusitanian Basin (Portugal). Com. Inst. Geol. Min. 83, 65-94.

(2004) - The geological heritage of the Lower Jurassic of Central Portugal: selected sites, inventory and main scientific arguments. Riv. Ital. Paleontol. Strat. 110 (1), 381-388. DOI: $\underline{10.13130 / 2039-4942 / 6315}$

(2007) - Lithostratigraphy, sequence stratigraphy and depositional setting of the Pliensbachian and Toarcian series in the Lusitanian Basin (Portugal). In: Rocha R. B. (Ed.), The Peniche section (Portugal). Contributions to the definition of the Toarcian GSSP. Int. Subcom. Jurassic Strat., 17-23.

Duarte L. V., Silva R. L. \& Mendonça Filho J. G. (2011) - The Lower Jurassic of west coast of Portugal: stratigraphy and organic matter in carbonate sedimentation. In: Flores M. $\&$ Marques M. (Eds.), Field Trip Guide Book $63^{\text {rd }}$ Annual 
Meeting Int. Comm. Coal Organic Petrology, Porto 2011. Mem. Fac. Ciênc. Univ. Porto 17, 1-42.

Duarte L. V., Silva R. L., Oliveira L. C. V., Comas-Rengifo M. J. \& Silva F. (2010) - Organic-rich facies in the Sinemurian and Pliensbachian of the Lusitanian Basin, Portugal: Total Organic Carbon distribution and relation to transgressive-regressive facies cycles. Geol. Acta 8, 325-340. DOI: $\underline{10.1344 / 105.000001536}$

Duarte L. V. \& Soares A. F. (2002) - Litostratigrafia das series margo-calcárias do Jurássico Inferior da Bacia Lusitânica (Portugal). Com. Inst. Geol. Min. 89, 135-154.

Duarte L. V., Wright V. P., Fernández-López S., Elmi S., Krautter M., Azerêdo A. C., Henriques M. H., Rodrigues R. \& Perilli N. (2004) - Early Jurassic carbonate evolution in the Lusitanian Basin (Portugal): facies, sequence stratigraphy and cyclicity In: Duarte L. V. \& Henriques M. H. (Eds.), Carboniferous and Jurassic Carbonate Platforms of Iberia. $23^{\text {rd }}$ IAS Meet. Sedimentology, Field Trip Guide Book 1, Coimbra, 45-71. http://eprints.ucm. es/23203/1/118\%2B119\%2B120_04 Early_Jurassic_Lusitanian_Basin.pdf

Elmi S. (2006) - Pliensbachian/Toarcian boundary: the proposed GSSP of Peniche (Portugal). Vol. Jurassica 4, 5-16.

Elmi S., Mouterde R., Rocha R. B. \& Duarte L. V. (1996) - La limite Pliensbachien-Toarcien au Portugal; intérêt de la coupe de Peniche. Aalenews 6, 33-35.

Elmi S., Rocha R. B. \& Mouterde R. (1988) - Sediméntation pélagique et encroûtements crytalgaires: les calcaires grumeleux du Carixien portugais. Ciências Terra 9, 69-90. http://cienciasdaterra.novaidfct.pt/index.php/ct-esj/article/ view/109

Fernández-López S., Duarte L. V. \& Henriques M. H. (2000) - Ammonites from lumpy limestones in the Lower Pliensbachian of Portugal: taphonomic analysis and paleoambiental implications. Rev. Soc. Geol. España 13 (1), 3-15. http:// www.sociedadgeologica.es/archivos/REV/13(1)/Art01.pdf

Ferreira R., Mendonça Filho J. G., Duarte L. V., Silva R. L. \& Mendonça J. O. (2010) - Hydrocarbon generation potential of the Pliensbachian organic-rich series of Peniche (Lusitanian Basin, Portugal): an organopetrographic and thermal maturation assessment integrated analysis. In: Reis R. P. \& Pimentel N. (Eds.), II Central \& North Atlantic Conjugate Margins Conf.: Extended Abstracts III, 116-120. https:// www.researchgate.net/publication/228758696 Hydrocarbon_generation_potential_of_the_Pliensbachian_organic-rich series of Peniche Lusitanian Basin Portugal An_organopetrographic_and thermal_maturation

França J. C., Zbyszewski G. \& Almeida F. M. (1960) - Carta geológica de Portugal, na escala 1/50 000. Notícia Explicativa da folha 26-C (Peniche). Serv. Geol. Portugal, 33 p.

Gradstein F. M., Ogg J. G., Schmitz M. \& Ogg G. (2012) - The Geologic Time Scale 2012. Elsevier, 1176 p.

Hesselbo S. P., Jenkyns H. C., Duarte L. V. \& Oliveira L. C. V. (2007) - Carbon-isotope record of the Early Jurassic (Toarcian) Oceanic Anoxic Event from fossil wood and marine carbonate (Lusitanian Basin, Portugal). Earth Planet. Sci. Lett. 253, 455-470. DOI: 10.1016/j.eps1.2006.11.009

Jenkyns H. C. \& Clayton C. J. (1986) - Black shales and carbon isotopes in pelagic sediments from the Tethyan Lower Jurassic. Sedimentology 33, 87-106. DOI: $\underline{10.1111 / j .13653091 .1986 . t b 00746 . x}$

Kemp D. B., Coe A. L., Cohen A. S. \& Weedon G. P. (2011) Astronomical forcing and chronology of the early Toarcian (Early Jurassic) oceanic anoxic event in Yorkshire, UK. Paleoceanography 26, PA4210, DOI: 10.1029/2011PA002122

Kullberg J. C., Rocha R. B., Soares A. F., Rey J., Terrinha P., Azerêdo A. C., Callapez P., Duarte L. V., Kullberg M. C., Martins L., Miranda J. R., Alves C., Mata J., Madeira J., Mateus O. \& Moreira M. (2013) - A Bacia Lusitaniana: Estratigrafia, Paleogeografia e Tectónica. In: Dias R., Araújo A., Terrinha P. \& Kullberg J. C. (Eds.), Geologia de Portugal no contexto da Ibéria. Vol. II - Geologia Meso-cenozóica de Portugal. Livr. Escolar Editora 195-347.

Léonide P., Floquet M., Durlet C., Baudin F., Pittet B. \& Lécuyer C. (2012) - Drowning of a carbonate platform as a precursor stage of the Early Toarcian global anoxic event (Southern Provence sub-Basin, South-east France). Sedimentology 59, 156-184. DOI: $10.1111 / \mathrm{j} .1365-3091.2010 .01221 . \mathrm{x}$

Mattioli E. \& Erba E. (1999) - Synthesis of calcareous nannofossil events in Tethyan Lower and Middle Jurassic successions. Riv. Ital. Paleont. Strat. 105, 343-376. http://riviste. unimi.it/index.php/RIPS/article/view/5380/5429

Mattioli E., Pittet B., Bucefalo Palliani R., Röhl H. J., SchmidRöhl A. \& Morettini E. (2004) - Phytoplankton evidence for the timing and correlation of palaeoceanographical changes during the Early Toarcian oceanic anoxic event (Early Jurassic). J. Geol. Soc. London 161, 685-693. DOI: $\underline{10.1144 / 0016-764903-074}$

Matiolli E., Pittet B., Petitpierre L. \& Mailliot S. (2009) - Dramatic decrease of pelagic carbonate production by nannoplankton across the Early Toarcian anoxic event (T-OAE). Global Plan. Change 65, 134-145. DOI: 10.1016/j.gloplacha.2008.10.018

Mattioli E., Pittet B., Suan G. \& Mailliot S. (2008) - Calcareous nannoplankton across the Early Toarcian Anoxic Event: implications for paleoceanography within the western Tethys. Paleoceanography 23, PA3208, DOI: $\underline{10.1029 / 2007 \mathrm{PA} 001435}$

Mattioli E., Plancq J., Boussaha M., Duarte L. V. \& Pittet B. (2013) - Calcareous nannofossil biostratigraphy: new data from the Lower Jurassic of the Lusitanian Basin. Com. Geológicas 100, fasc. esp. I, 69-76. http://www.lneg.pt/ download/6620/10_ART_CG13 ESPECIAL_I+ Editores FINAL corr3.pdf

Morard A., Guex J., Bartolini A., Morettini E. \& De Wever P. (2003) - A new scenario for the Domerian - Toarcian transition. Bull. Soc. Géol. France 174, 351-356. DOI: 10.2113/174.4.351

Mouterde R. (1955) - Le Lias de Peniche. Com. Serv. Geol. Portugal 36, 5-33. 
Mouterde R., Dommergues J.-L., Meister C. \& Rocha R. B. (2007) - Atlas des fossiles caractéristiques du Lias portugais. III a) Domérien (Ammonites). Ciências Terra 16, 67-111. http://cienciasdaterra.novaidfct.pt/index.php/ct-esj/ article/view/201

N'zaba-Makaya O., Andreu B., Brunel F., Mouterde R., Rey J. \& Rocha R. (2003) - Biostratigraphie et paléoécologie des peuplements d'ostracodes dans le Domérien du Bassin Lusitanien, Portugal. Ciências Terra 15, 21-44. http://cienciasdaterra.novaidfct.pt/index.php/ct-esj/article/view/2

Oliveira L. C. V., Duarte L. V., Lemos V. B., Comas-Rengifo M. J. \& Perilli N. (2007) - Bioestratigrafia de nanofósseis calcários e correlação com as zonas de amonites do Pliensbaquiano-Toarciano basal (Jurássico inferior) de Peniche (Bacia Lusitânica, Portugal). Proc. XIX Congr. Brasil. Paleont., Búzios, 411-420.

Oliveira L. C. V., Rodrigues R., Duarte L. V. \& Lemos V. (2006) - Avaliação do potencial gerador de petróleo e interpretação paleoambiental com base em biomarcadores e isótopos estáveis do carbono da seção Pliensbaquiano-Toarciano inferior (Jurássico inferior) da região de Peniche (Bacia Lusitânica, Portugal). Bol. Geoc. Petrobras 14 (2), 207-234. https://estudogeral.sib.uc.pt/handle/10316/20112

Paredes R., Comas-Rengifo M. J. \& Duarte L. V. (2013) Moluscos bivalves da Formação de Água de Madeiros (Sinemuriano Superior) da Bacia Lusitânica (Portugal). Com. Geológicas 100, fasc. esp. I, 21-27. http://www.lneg. pt/download/6638/3 ART_CG13 ESPECIAL_I\%20 Editores_FINAL_corr4_ult3.pdf

Perilli N. \& Duarte L. V. (2006) - Toarcian nannobiohorizons from the Lusitanian Basin (Portugal) and their calibration against ammonite zones. Riv. Ital. Paleontol. Strat. 112, 417-434. DOI: $10.13130 / 2039-4942 / 6350$

Phelps M. (1985) - A refined ammonite biostratigraphy for the Middle and Upper Carixian (Ibex and Davoei zones, Lower Jurassic) in North-West Europe and stratigraphical details of the Carixian-Domerian boundary. Geobios 18, 321-362. DOI: 10.1016/S0016-6995(85)80098-X

Reale V., Baldanza A., Monechi S. \& Mattioli E. (1992) - Calcareous nannofossil biostratigraphic events from the Early-Middle Jurassic sequences of the Umbria-Marche area (Central Italy). Mem. Sc. Geol. Padova 43, 41-75.

Reggiani L., Mattioli E. \& Pittet B. (2010a) - Spatial distribution of Late Pliensbachian (Early Jurassic) calcareous nannofossils within the Lusitanian basin (Portugal). Geobios, 43 (1), 87-97. DOI: 10.1016/j.geobios.2009.06.005

Reggiani L., Mattioli E., Pittet B., Duarte L. V., Oliveira L. C. V. \& Comas-Rengifo M. J. (2010b) - Pliensbachian (Early Jurassic) calcareous nannofossils from the Peniche section (Lusitanian Basin, Portugal): A clue for palaeoenvironmental reconstructions. Mar. Micropaleontol. 75 (1-4), 1-16. DOI: 10.1016/j.marmicro.2010.02.002

Rocha R. B. (Ed.) (2007) - The Peniche section (Portugal). Contributions to the definition of the Toarcian Global Stratotype Section and Point (GSSP). Int. Subcom. Jurassic Strat., Lisboa, $66 \mathrm{p}$.
Rocha R. B., Duarte L. V., Mattioli E., Elmi S., Mouterde R., Cabral M. C, Comas-Rengifo M. J., Gómez J. J., Goy A., Hesselbo S. P., Jenkyns H. C., Littler K., Mailliot S., Oliveira L. C. V., Osete M. L., Perilli N., Pinto S., Pittet B., Ruget Ch. \& Suan G. (2013) - Formal proposal for the Global Boundary Stratotype Section and Point (GSSP) of the Toarcian Stage, at the base of the Polymorphum Zone in the Peniche section (Portugal). Int. Subcom. Jurassic Strat., Toarcian Task Group, $60 \mathrm{p}$.

Röhl H. J. \& Schmid-Röhl A. (2005) - Lower Toarcian (Upper Liassic) black shales of the Central European epicontinental basin: a sequence stratigraphic case study from the SW German Posidonia Shale. in: Deposition of OrganicCarbon-Rich Sediments: Models, Mechanisms, and Consequences, SEPM Spec. Publ. 82, 165-189. https://www. researchgate.net/publication/266087280_Lower_Toarcian Upper_Liassic_Black_Shales of the Central_European Epicontinental_Basin_A_Sequence_Stratigraphic_Case Study from the Sw_German_Posidonia_Shale

Sabatino N., Neri R., Bellanca A., Jenkyns H. C., Baudin F., Parisi G. \& Masetti D. (2009) - Carbon-isotope records of the Early Jurassic (Toarcian) oceanic anoxic event from the Valdorbia (Umbria-Marche Apennines) and Monte Mangart (Julian Alps) sections: palaeoceanographic and stratigraphic implications. Sedimentology 56, DOI: 10.1111/j.13653091.2008.01035.X

Silva R. L. (2013) - Séries carbonatadas ricas em matéria orgânica do Jurássico da Bacia Lusitânica (Portugal): Sedimentologia, Geoquímica e interpretação paleoambiental. PhD thesis Univ. Coimbra (unpublished), 224 p. https:// estudogeral.sib.uc.pt/handle/10316/23709

Silva R. L., Duarte L. V., Azerêdo A. C. \& Mendonça Filho J. G. (2011a) - Contributos sedimentológicos e geoquímicos para a modelação dos sistemas petrolíferos portugueses: as séries jurássicas ricas em matéria orgânica da Bacia Lusitânica (Portugal). In: Neves L. J. P. F., Pereira A. J. S. C. , Gomes C. S. R. , Pereira L. C. G. \& Tavares A. O. (Eds.),Modelação de Sistemas Geológicos. Lab. Radioact. Natural Univ. Coimbra, 383-391. DOI: 10.14195/978- 989-26-1009$\underline{2} 29$

Silva R. L., Duarte L. V., Comas-Rengifo M. J., Mendonça Filho J. G. \& Azerêdo A. C. (2011b) - Update of the carbon and oxygen isotopic records of the Early-Late Pliensbachian (Early Jurassic, $\sim 187 \mathrm{Ma}$ ): Insights from the organic-rich hemipelagic series of the Lusitanian Basin (Portugal). Chem. Geol. 283, 177-184. DOI: 10.1016/j.chemgeo.2011.01.010

Silva R. L., Mendonça Filho J. G., Duarte L. V., Comas-Rengifo M. J., Azerêdo A. C. \& Ferreira R. (2010) - Organic-rich facies of the top Ibex-Margaritatus zones (Pliensbachian) of the Lusitanian Basin (Portugal): TOC and biomarkers variation. Geochim. Cosmochim. Acta 74 (12-S1), A962. https://www.goldschmidtabstracts.info/abstracts/abstractView?id=2010001989

Silva R. L., Mendonça Filho J. G., Silva F. S., Duarte L. V., Silva T. F., Ferreira R. \& Azerêdo A. C. (2012) - Can biogeochemistry aid in the palaeoenvironmental/early diagenesis reconstruction of the $\sim 187 \mathrm{Ma}$ (Pliensbachian) organic-rich 
hemipelagic series of the Lusitanian Basin (Portugal)?. Bull. Geosci. 87, 373-382. DOI: 10.3140/bull.geosci.1315

Soares A. F., Rocha R. B., Elmi S., Henriques M. H., Mouterde R., Almeras Y., Ruget C., Marques J., Duarte L., Carapito C. \& Kullberg J. C. (1993) - Le sous-bassin nord-lusitanien (Portugal) du Trias au Jurassique moyen: histoire d'un "rift avorté". C. R. Acad. Sc. Paris 317, sér. II, 1659-1666. https://www.researchgate.net/publication/233785811_Le sous-bassin nord lusitanien Portugal du Trias au Jurassique moyen histoire dun rift avorte C R R Ac_Sc Paris_t_317_Ser_II_1659-1666

Suan G., Mattioli E., Pittet B., Lécuyer C., Suchéras-Marx B., Duarte L. V., Philippe M., Reggiani L. \& Martineau F. (2010) - Secular environmental precursors to Early Toarcian (Jurassic) extreme climate changes. Earth Planet. Sci. Lett. 290, 448-458. DOI: $10.1016 /$ j.eps1.2009.12.047

Suan G., Mattioli E., Pittet B., Mailliot B. \& Lécuyer C. (2008a) - Evidence for major environmental perturbation prior to and during the Toarcian (Early Jurassic) oceanic anoxic event from the Lusitanian Basin, Portugal. Paleoceanography 23, PA1201, DOI: $10.1029 / 2007$ PA001459

Suan G., Pittet B., Bour I., Mattioli E., Duarte L. V. \& Mailliot
S. (2008b) - Duration of the Early Toarcian carbon isotope excursion deduced from spectral analysis: consequence for its possible causes. Earth Planet. Sci. Lett. 267, 666-679. DOI: $\underline{10.1016 / \text { j.eps1.2007.12.017 }}$

Wignall P. B. (1991) - Model for transgressive black shales? Geology 19, 167-170. DOI: 10.1130/0091-7613(1991)019<0167:MFTBS >2.3.CO;2

Wilson R. C. L., Hiscott R. N., Willis M. G. \& Gradstein F. M. (1989) - The Lusitanian Basin of West-central Portugal: Mesozoic and Tertiary tectonic, stratigraphic and subsidence history. In: Tankard A. J. \& Balkwill H. R. (Eds.), Extensional tectonics and stratigraphy of the North Atlantic margins. A.A.P.G. Mem. 46, 341-361. https://www. researchgate.net/publication/284337703 The Lusitanian Basin_of_west-central_Portugal_Mesozoic_and Tertiary tectonic stratigraphic and subsidence history

Wright V. P. \& Wilson R. C. L. (1984) - A carbonate submarine-fan sequence from the Jurassic of Portugal. J. Sedim. Petrol. 54, 394-412.DOI: 10.1306/212F8427-2B24-11D78648000102C1865D or https://www.researchgate.net/publication/291999068_A_Carbonate_Submarine-Fan_Sequence_from the_Jurassic_of_Portugal 